\title{
Commentary
}

\section{The Link Between Human and Transgenic Animal Studies Involving Postprandial Hypertriglyceridemia and CETP Gene Polymorphisms}

\author{
Genovefa D Kolovou $^{1, *}$, Katherine K Anagnostopoulou ${ }^{1}$ and Dimitri P Mikhailidis ${ }^{2}$ \\ ${ }^{I} 1^{\text {st }}$ Cardiology Department, Onassis Cardiac Surgery Center Athens, Greece, ${ }^{2}$ Department of Clinical Biochemistry \\ (Vascular Prevention Clinics), Royal Free campus, University College London Medical School, University College \\ London London, UK
}

During last decades a considerable attempt has been made to prevent cardiovascular disease (CVD). Nevertheless, CVD remains a leading cause of death world wide [1]. The guidelines of medical scientific societies for primary and secondary prevention of CVD are directed towards established CVD risk factors (dyslipidemia, diabetes mellitus, hypertension, obesity, smoking and others). As far as dyslipidemia is concerned, the first priority, according to the guidelines [2], is to achieve optimal low density lipoprotein cholesterol (LDL-C) levels. Many clinical trials have shown that hypolipidemic treatment besides lowering LDL-C also significantly reduces CVD-related morbidity and mortality [3, 4]. Nevertheless, a considerable number of treated subjects still have CVD events. Thus, the need for additional therapeutic treatment such as increasing high density lipoprotein cholesterol (HDL-C) levels and decreasing levels of triglycerides (TG) has been suggested [5]. In this context, torcetrapib, an inhibitor of cholesteryl ester transport protein (CETP), increased HDL-C levels and decreased LDL-C levels [6-8]. However, the drug was withdrawn due to side effects.

Another potential target to reduce CVD risk is postprandial hypertriglyceridemia [9, 10]. In 1979, Zilversmit [11] proposed that TG are involved in development of atherosclerosis. Since then, many research teams, including ours, [1215] have examined the role of the exaggerated and delayed clearance of postprandial lipoprotein particles in various diseases $[16,17]$ including CVD. The mechanisms involved in postprandial lipemia were reviewed [18]. Considering all the above, the ideal gene associated with all 3 (TG, HDL and postprandial hypertriglyceridemia) is the one encoding for CETP.

The mechanisms by which the CETP controls lipid metabolism have attracted many investigators, especially when plasma CETP concentration was found to be associated with the increased risk for premature atherosclerosis [19]. CETP activity depends on several factors such as environmental components (e.g. diet [20], alcohol consumption [21] and smoking [22]) gender [23] and genetic influence (e.g. polymorphisms of CETP) [24-26].

\footnotetext{
*Address correspondence to this author at the Onassis Cardiac Surgery Center, 356 Sygrou Ave 17674 Athens, Greece; Tel: +30 210 9493520; Fax: +30 210 9493336; E-mail: genovefa@kolovou.com
}

Few months ago, Salerno et al. examined the association between CETP and postprandial hypertriglyceridemia in transgenic mice [27]. They performed functional studies to show that plasma CETP activity modifies postprandial response of TG-rich lipoproteins. They assessed the TG response to fat load in rats with introduced human CETP gene (mice and rats are naturally CETP deficient). They found that elevated levels of CETP were associated with fat intolerance.

Genetically, engineered mice have proven to be valid models for the study of CETP function and its relation with atherosclerosis. Introduction of the human CETP gene into mice results in a dose-related reduction of HDL-C levels and, as a consequence, these animals have significantly more early atherosclerotic lesions in the proximal aorta than control mice [28]. CETP variants have a strong impact on CETP activity and thus on HDL-C levels [29]. Several polymorphisms have been identified in the coding sequence of the CETP gene including I405V [30]. The I405V polymorphism has been associated with reduced CETP mass, increased HDL-C levels and increased CVD risk [31, 32]. Another widely studied CETP polymorphism is TaqIB which seems to influence HDL-C levels [33]. In normolipidemic subjects, the absence of the TaqIB restriction site (B2 allele) is associated with decreased CETP activity, increased HDL-C levels and reduced risk of CVD in males compared with $\mathrm{B} 1$ subjects [19]. The CETP TaqIB polymorphism has been found to account for $5.8 \%$ of the variance in HDL-C, which is important since the $1 \mathrm{mg} / \mathrm{dl}$ increase of HDL-C leads to $2 \%$ decrease in CVD risk [33, 34]. Subjects with the B2 allele usually have lower levels of CETP, higher levels of HDL-C and reduced risk of CHD compared with B1 subjects [33]. Our group also analyzed the association between TaqIB polymorphism and fasting as well as postprandial TG levels in heterozygote familial hypercholesterolemia $(\mathrm{hFH})$ patients [35]. The B1 allele carriers with exaggerate TG response to fat loading had higher fasting and postprandial TGs compared with B2 allele carriers. Also, patients with the B1B2 genotype had significantly higher HDL-C levels compared with the B1B1 genotype. Noone et al. found that B1 allele carriers had increased mass and activity of CETP at $6 \mathrm{~h}$ after fat loading compared with B2 allele carriers [36]. This finding is similar to our results (higher TG 6 and $8 \mathrm{~h}$ after fat loading in B1 allele carriers compared with B2; 
$\mathrm{p}<0.05$ and $\mathrm{p}<0.042$, respectively). This was in accordance with other studies as well. Tall et al. found a 1.1-1.7-fold increase in CETP in response to a $135-\mathrm{g}$ fat meal [37]. It has been shown by others $[38,39]$ and by us that carriers of the B1 allele have a more atherogenic fasting and non fasting lipid profile (low HDL-C, increased TGs, exaggerated and delayed clearance of TGs postprandially) than carriers of the B2 allele, which should lead to increased cardiovascular risk. Furthermore, Hogue et al. reported that a high plasma CETP concentration was associated with higher risk of having small-diameter particles of LDL in hFH patients, suggesting that CETP-induced remodeling of LDL is dependent on the number of TG-rich lipoproteins [40]. Also, in a previous study of ours [41] a significant gender association between TG response after oral fat loading and TaqIB polymorphism of the CETP gene in subjects with a exaggerate response was found. Specifically, men carrying the B2 allele of the TaqIB polymorphism showed a higher postprandial TG peak and a delayed return to baseline values compared with women carrying the B2 allele. The mechanisms of this observation were explained by Salerno et al. [27]. They reported that CETP expression in transgenic mice delays plasma clearance and liver uptake of TG-rich lipoproteins firstly, by transferring TGs to HDLs and increasing cholesteryl ester concentration of the remnant particles, and secondly by decreasing lipoprotein lipase (LPL) expression. Similarly, Zhou et al. [42] also found that adipocytes from adipose tissue of transgenic mice (CETP expressing) presented reduced LPL expression. The mechanisms underlying the differential lipemic responses confirmed in CETP expressing and nonexpressing transgenic animals could also be applicable for humans expressing high or low CETP activities. Thus, the human studies performed by our group presented similar positive associations between CETP and TG levels [35]. Two other studies have also shown similar results [43, 44].

A new aspect linked to the effects of CETP expression contribute to a better understanding of the influence of a precise gene on lipids and lipoproteins responsiveness to nutritional fat. This research carried out in either humans or transgenic animals may have clinical implications in the near future. The understanding of postprandial lipemia is important, since postprandial hypertriglyceridemia is involved in endothelial dysfunction, oxidative stress, small dense LDL and small dense HDL particles [45].

\section{REFERENCES}

[1] de Grooth GJ, Klerkx AH, Stroes ES, Stalenhoef AF, Kastelein JJ, Kuivenhoven JA. A review of CETP and its relation to atherosclerosis. J Lipid Res 2004; 45: 1967-74.

[2] Executive summary of the Third Report of the National Cholesterol Education Program (NCEP) Expert Panel on Detection, Evaluation, and Treatment of High Blood Cholesterol in Adults (Adult Treatment Panel III). JAMA 2001; 285: 2486-97.

[3] Scandinavian Simvastatin Survival Study Group. Randomised trial of cholesterol lowering in 4444 patients with coronary heart disease: the Scandinavian Simvastatin Survival Study (4S). Lancet 1994; 344: 1383-9.

[4] Sacks FM, Pfeffer MA, Moye LA, et al. The effect of pravastatin on coronary events after myocardial infarction in patients with average cholesterol levels. Cholesterol and Recurrent Events Trial Investigators. N Engl J Med 1996; 335: 1001-9.

[5] Gotto AM Jr. Low high-density lipoprotein cholesterol as a risk factor in coronary heart disease: a working group report. Circulation 2001; 103: 2213-8.
[6] de Grooth GJ, Kuivenhoven JA, Stalenhoef AF, et al. Efficacy and safety of a novel cholesteryl ester transfer protein inhibitor, JTT-705, in humans: a randomized phase II dose-response study. Circulation 2002; 105: 2159-65.

[7] Brousseau ME, Schaefer EJ, Wolfe ML, et al. Effects of an inhibitor of cholesteryl ester transfer protein on HDL cholesterol. N Engl J Med 2004; 350: 1505-15.

[8] Clark RW, Sutfin TA, Ruggeri RB, Willauer AT, et al. Raising high-density lipoprotein in humans through inhibition of cholesteryl ester transfer protein: an initial multidose study of torcetrapib. Arterioscler Thromb Vasc Biol 2004; 24: 490-7.

[9] Alipour A, Elte JW, van Zaanen HC, Rietveld AP, Castro Cabezas M. Novel aspects of postprandial lipemia in relation to atherosclerosis. Atheroscler Suppl 2008; 9: 39-44.

[10] Kapoor JR. Postprandial triglyceride levels and cardiovascular risk. Am Fam Physician 2008; 77: 1504.

[11] Zilversmit DB. Atherogenesis: a postprandial phenomenon. Circulation 1979; 60: 473-85.

[12] Kolovou GD, Daskalova DCh, Iraklianou SA, et al. Postprandial lipemia in hypertension. J Am Coll Nutr 2003; 22: 80-7.

[13] Kolovou G, Daskalova D, Anagnostopoulou K, et al. Postprandial hypertriglyceridaemia in patients with Tangier disease. J Clin Pathol 2003; 56: 937-41.

[14] Kolovou GD, Anagnostopoulou KK, Pilatis ND, et al. Heterozygote men with familial hypercholesterolaemia may have an abnormal triglyceride response post-prandially. Evidence for another predictor of vascular risk in familial hypercholesterolaemia. Int $\mathbf{J}$ Clin Pract 2005; 59: 311-7.

[15] Kolovou GD, Anagnostopoulou KK, Pavlidis AN, et al. Postprandial lipemia in men with metabolic syndrome, hypertensives and healthy subjects. Lipids Health Dis 2005; 4: 21.

[16] Nordestgaard BG, Benn M, Schnohr P, Tybjaerg-Hansen A. Nonfasting triglycerides and risk of myocardial infarction, ischemic heart disease, and death in men and women. JAMA 2007; 298: 299-308.

[17] Granér M, Kahri J, Nakano T, et al. Impact of postprandial lipaemia on low-density lipoprotein (LDL) size and oxidized LDL in patients with coronary artery disease. Eur J Clin Invest 2006; 36: 764 70 .

[18] Kolovou GD, Anagnostopoulou KK, Daskalopoulou SS, Mikhailidis DP, Cokkinos DV. Clinical relevance of postprandial lipaemia. Curr Med Chem 2005; 12: 1931-45.

[19] Ordovas JM, Cupples LA, Corella D, et al. Association of cholesteryl ester transfer protein-TaqIB polymorphism with variations in lipoprotein subclasses and coronary heart disease risk: the Framingham study. Arterioscler Thromb Vasc Biol 2000; 20: 13239.

[20] Li TY, Zhang C, Asselbergs FW, et al. Interaction between dietary fat intake and the cholesterol ester transfer protein TaqIB polymorphism in relation to HDL-cholesterol concentrations among US diabetic men. Am J Clin Nutr 2007; 86: 1524-9.

[21] Volcik K, Ballantyne CM, Pownall HJ, Sharrett AR, Boerwinkle E. Interaction effects of high-density lipoprotein metabolism gene variation and alcohol consumption on coronary heart disease risk: the atherosclerosis risk in communities study. J Stud Alcohol Drugs 2007; 68: 485-92.

[22] Goldenberg I, Moss AJ, Block R, et al. Polymorphism in the cholesteryl ester transfer protein gene and the risk of early onset myocardial infarction among cigarette smokers. Ann Noninvasive Electrocardiol 2007; 12: 364-74.

[23] Alssema M, Dekker JM, Kuivenhoven JA, et al. Elevated cholesteryl ester transfer protein concentration is associated with an increased risk for cardiovascular disease in women, but not in men, with Type 2 diabetes: the Hoorn Study. Diabet Med 2007; 24: 11723.

[24] Thompson A, Di Angelantonio E, Sarwar N, et al. Association of cholesteryl ester transfer protein genotypes with CETP mass and activity, lipid levels, and coronary risk. JAMA 2008; 299: 2777-88.

[25] Tsai MY, Johnson C, Kao WH, et al. Cholesteryl ester transfer protein genetic polymorphisms, HDL cholesterol, and subclinical cardiovascular disease in the Multi-Ethnic Study of Atherosclerosis. Atherosclerosis 2008; 200: 359-67.

[26] Kolovou GD, Anagnostopoulou KK, Karyofillis P, et al. Cholesteryl ester transfer protein gene polymorphisms and severity of coronary stenosis. Clin Invest Med 2006; 29: 14-9. 
[27] Salerno A, Patrício P, Berti J, Oliveira H. Cholesteryl ester transfer protein (CETP) increases postprandial triglyceridemia and delays triglyceride plasma clearance in transgenic mice. Biochem J 2009; 419: 629-34

[28] Marotti KR, Castle CK, Boyle TP, Lin AH, Murray RW, Melchior GW. Severe atherosclerosis in transgenic mice expressing simian cholesteryl ester transfer protein. Nature 1993; 364: 73-5.

[29] Gudnason V, Kakko S, Nicaud V, et al. Cholesteryl ester transfer protein gene effect on CETP activity and plasma high-density lipoprotein in European populations. The EARS Group. Eur J Clin Invest 1999; 29: 116-28.

[30] Agellon LB, Quinet EM, Gillette TG, Drayna DT, Brown ML, Tall AR. Organization of the human cholesteryl ester transfer protein gene. Biochemistry 1990; 2: 1372-6.

[31] Kuivenhoven JA, de Knijff P, Boer JM, et al. Heterogeneity at the CETP gene locus. Influence on plasma CETP concentrations and HDL cholesterol levels. Arterioscler Thromb Vasc Biol 1997; 17: 560-8.

[32] Agerholm-Larsen B, Nordestgaard BG, Steffensen R, Jensen G, Tybjaerg-Hansen A. Elevated HDL cholesterol is a risk factor for ischemic heart disease in white women when caused by a common mutation in the cholesteryl ester transfer protein gene. Circulation 2000; 101: 1907-12.

[33] Corella D, Sáiz C, Guillén M, et al. Association of TaqIB polymorphism in the cholesteryl ester transfer protein gene with plasma lipid levels in a healthy Spanish population. Atherosclerosis 2000; 152: 367-76.

[34] Kapur NK, Ashen D, Blumenthal RS. High density lipoprotein cholesterol: an evolving target of therapy in the management of cardiovascular disease. Vasc Health Risk Manag 2008; 4: 39-57.

[35] Kolovou G, Anagnostopoulou K, Kostakou P, et al. Association between the TaqIB polymorphism in the cholesteryl ester transfer protein gene locus and postprandial plasma lipoprotein levels in heterozygotes for familial hypercholesterolemia. Clin Chem Lab Med 2007; 45: 1190-8.
[36] Noone E, Roche HM, Black I, Tully AM, Gibney MJ. Effect of postprandial lipaemia and Taq 1B polymorphism of the cholesteryl ester transfer protein (CETP) gene on CETP mass, activity, associated lipoproteins and plasma lipids. Br J Nutr 2000; 84: 203-9.

[37] Tall A. Plasma lipid transfer proteins. Annu Rev Biochem 1995; 64: 235-57.

[38] Kuivenhoven JA, Jukema JW, Zwinderman AH, et al. The role of a common variant of the cholesteryl ester transfer protein gene in the progression of coronary atherosclerosis. The Regression Growth Evaluation Statin Study Group. N Engl J Med 1998; 338: 86-93.

[39] Thu NN, Mai TT, Ohmori R, et al. Effect of the cholesteryl ester transfer protein genotypes on plasma lipid and lipoprotein levels in Vietnamese children. Pediatr Res 2005; 58: 1249-53.

[40] Hogue JC, Lamarche B, Gaudet D, et al. Relationship between cholesteryl ester transfer protein and LDL heterogeneity in familial hypercholesterolemia. J Lipid Res 2004; 45: 1077-83.

[41] Anagnostopoulou KK, Kolovou GD, Kostakou PM, et al. Sexassociated effect of CETP and LPL polymorphisms on postprandial lipids in familial hypercholesterolaemia. Lipids Health Dis 2009 (in press).

[42] Zhou H, Li Z, Hojjati MR, et al. Adipose tissue-specific CETP expression in mice: impact on plasma lipoprotein metabolism. J Lipid Res 2006; 47: 2011-9.

[43] Ye SQ, Kwiterovich PO Jr. Influence of genetic polymorphisms on responsiveness to dietary fat and cholesterol. Am J Clin Nutr 2000; 72: $1275-84$.

[44] Inazu A, Nakajima K, Nakano T, et al. Decreased post-prandial triglyceride response and diminished remnant lipoprotein formation in cholesteryl ester transfer protein (CETP) deficiency. Atherosclerosis 2008; 196: 953-7.

[45] Stalenhoef AF, de Graaf J. Association of fasting and nonfasting serum triglycerides with cardiovascular disease and the role of remnant-like lipoproteins and small dense LDL. Curr Opin Lipidol 2008; 19: 355-61.

(C) Kolovou et al.; Licensee Bentham Open.

This is an open access article licensed under the terms of the Creative Commons Attribution Non-Commercial License (http://creativecommons.org/licenses/by$\mathrm{nc} / 3.0 /$ ) which permits unrestricted, non-commercial use, distribution and reproduction in any medium, provided the work is properly cited. 